\title{
Un patronazgo en conflicto. La Virgen de Peña Sacra y su cofradía de Madrid (siglos XVII-XVIII)
}

La devoción a la Virgen de Peña Sacra en Manzanares el Real forma parte del sentir actual de sus habitantes. Elegida copatrona de la localidad con los mismos honores que el Santísimo Cristo de la Nave, ambos forman parte de la cúpula más querida de los seres sagrados venerados entre sus feligreses. Sin embargo, a diferencia de muchas otras localidades de este país, el proceso de formación de esta cúpula devocional estuvo marcado por importantes incidentes que pudieron cambiar los rasgos más característicos de su culto, de sus formas devocionales corporeizadas en los modos rituales e incluso de su capacidad para convertirse en un hito altamente simbólico del territorio religioso local. En este sentido, analizar las relaciones de patronazgo entre una imagen religiosa y un grupo social definido tiene un cierto interés cuando su enfoque teórico va encaminado hacia las consabidas materializaciones del fortalecimiento de las identidades implicadas en dichos cultos. Pero todo parece indicar también que unas nuevas dimensiones pueden aflorar cuando el análisis de estas relaciones de patronazgo hace patente una cierta multiplicidad de situaciones en las que los agentes implicados demuestran que su campo de actuación es singularmente dinámico y plural ${ }^{1}$. En este sentido, el caso histó-

1 No es cuestión aquí de exponer mayores datos respecto a este planteamiento básico, pero sí de dejar clara cierta diferenciación metodológica. Para los símbolos religiosos como generadores de identidad en nuestro país: ver Carmelo LISÓN TOLOSANA, "Aragón festivo (la fiesta como estrategia simbólica)", Antropología social y bermenéutica (México: FCE, 1983), pp. 43-84; Andrés BARRERA, La dialéctica de la identidad en Cataluña. Un estudio de antropología social (Madrid: CIS, 1985); Antonio ARIÑO, Festes, ritual i creences (Valencia: Ed. Alfons el Magnanim, 1988); Carlos Álvarez SANTAló, María Jesús BuXó y Salvador RodríGuez BECERRA (coords.), La religiosidad popular (Barcelona: Anthropos, 1989) (Tomo III en especial); Juan AGUDO ToRRICO, Las hermandades de la Virgen de Guía en Los Pedroches (Córdoba: Caja Provincial, 1990); Ana RIVAS, "Mediación divina y negociación ritual en los conflictos de indentidad: la creación simbólica de fronteras", Revista de Antropología Social, 3 (1994), pp. 27-45, entre otros muchos. En cuanto a los contextos más amplios, ver William CHRistian, Religiosidad local en la España de Felipe II (Madrid: Nerea, 1991); Angelo TORRE, "Politics cloaked in worship: state, church and local power in Piedmond (1570-1770)", Past and Present, 134 (1994), pp. 42-92; Honorio VelasCO, "La apropiación de los símbolos 
rico analizado en este trabajo ya deja entrever, desde la raíz de su contexto, la búsqueda de nuevos planteamientos plenamente satisfactorios. En efecto, las relaciones devocionales entre esta particular imagen religiosa (Nuestra Señora de Peña Sacra) y la comunidad local que la venera (Manzanares el Real), iniciadas históricamente al menos desde el siglo Xv, se vieron mediatizadas por la presencia de un elemento externo que distorsionó la consolidación histórica de un proceso de patronazgo, desde mediados del siglo XVII hasta finales de la centuria siguiente. Condicionante que dejó marcado para siempre el paisaje devocional de la localidad. Por ello, en el caso que se va a analizar, las relaciones símbolo sagrado/comunidad no podían ser meramente binarias, ni sometidas al desarrollo de los agentes locales implicados en el culto. Este tercer elemento dejó abierta la posibilidad de introducir nuevos planteamientos teóricos, que son los que se van a comentar a continuación ${ }^{2}$.

El trabajo está dividido en tres partes. La primera se refiere al análisis de un peculiar contexto, el de la ciudad de Madrid en los siglos XVII y XVIII, haciendo hincapié en un aspecto importante de su intrínseca geografía religiosa, el culto a las imágenes ubicadas en dos de sus conventos. Podremos contemplar las diferentes cofradías que allí veneraron a sus símbolos sagrados preferidos, las formas adoptadas para conseguir un locus adecuado, fruto de las intensas negociaciones entre hermandad y convento, las dificultades para mantener los cultos más aptos y la derivada y extrema movilidad de muchos grupos de cofrades en busca de cierto equilibrio devocional. En el seno de esta geografía religiosa madrileña, debemos insertar la experiencia de creación de la cofradía que pretendió dar culto a una imagen que ya se veneraba a más de cuarenta kilómetros de distancia, los avatares de sus intentos y las estrategias tomadas por sus juntas directivas a lo largo de los años; estos puntos serán tratados en una segunda parte para pasar, finalmente, al análisis de las formas elegidas por dicha cofradía para descontextualizar los modos rituales que los agentes locales desarrollaron en torno al culto de la Virgen, dejando aflorar las múltiples y variadas reacciones de las instituciones implicadas, así como de sus representantes.

sagrados. Historias y leyendas de imágenes y santuarios (siglos XV-XviII)", Revista de Antropología Social, 5 (1996), pp. 83-114; y Honorio VelASCO, "Sobre ofrendas y exvotos", Es un voto. Exvotos pictóricos en La Rioja (Logroño: Fundación Caja Rioja, 1997), pp. 19-118, entre otros.

2 El planteamiento general se ha debatido con mayores detalles en mi tesis doctoral: Iglesia universal e iglesias locales. Un estudio antropológico de la religiosidad local de Colmenar Viejo y su comarca (UNED, 1997). Agradezco desde aquí los comentarios críticos de Joan Prat, Ángel Díaz de Rada, Antonio Cea, Salvador Rodríguez Becerra, Antonio Ariño y Honorio Velasco. 
LAS COFRADÍAS EN LOS CONVENTOS: LA DINÁMICA DE UNA GEOGRAFÍA RELIGIOSA MADRILEÑA

Dentro de lo que se conoce en la disciplina antropológica como el análisis del territorio, existe un interés renovado por la posibilidad de ofrecer unas pautas significativas respecto a los espacios sagrados. Cualquier territorio (incluido el religioso) es construido culturalmente por sus moradores. En cuanto al más específicamente religioso, a diferencia de otros tipos, se caracteriza por la construcción de una red de puntos altamente diferenciadores que pretenden entrelazar el destino de los dioses con el de los humanos; son elementos nodales que articulan todo su conjunto. Siguiendo a Peter Brown, consideraremos dichos puntos nodales como lugares privilegiados de la corporeización de lo sagrado, en forma de símbolos religiosos con la suficiente atracción devocional para convertirse en elementos focalizadores, socialmente centrífugos, de la devoción ${ }^{3}$. Las imágenes religiosas llevan en sí la posibilidad de convertirse en vasos comunicantes entre dos mundos separados, confrontan los espacios interiores de una comunidad implicados en la vida religiosa y tejen una red marcada por selectivos puntos altamente atractivos para sus habitantes. Esta geografía religiosa del Madrid de los siglos XVII y XVIII está articulada por las particulares ubicaciones de las numerosas imágenes sagradas que la configuran, destacando varios niveles de atracción de fieles. Sin ahondar en mayores detalles (ya que un extenso análisis de una geografía religiosa madrileña está por hacer), son cuatro los propuestos: primero encontraríamos el nivel de las imágenes religiosas concentradas en el seno de las iglesias parroquiales de la ciudad. En segundo lugar, estarían otras, ubicadas en los diferentes conventos de la capital. En tercer lugar, aquellos símbolos religiosos titulares de las ermitas alejadas del casco urbano y finalmente, en el cuarto nivel, las imágenes religiosas ubicadas en santuarios alejados de Madrid, aunque, según los historiadores, siempre a una distancia razonable para realizar un viaje de ida y vuelta en el día ${ }^{4}$. Este

3 La devoción hacia las imágenes de una determinada geografía religiosa es, por lo tanto, entendida como la consecución de un intercambio entre fieles y seres sagrados; relación que se concreta en la atracción de los devotos hacia aquellos lugares donde se ubican las imágenes sagradas, en espera de recibir alguna gracia divina. Ver Peter Brown, Le culte des saints (Paris: Cerf, 1984).

4 Respecto a los santuarios comarcales de Madrid, ver Ángela MUÑOz FERNÁNDEZ, "Santuarios locales y circulación devocional en la Tierra y Arciprestazgo madrileños", Cristina SEgura (ed.), Caminos y caminantes por las tierras del Madrid medieval (Madrid, 1994), pp. 225-280. Por otra parte, no se incluye en esta tipología a los hospi- 
esquema básico permite valorar mejor las diferencias entre los puntos nodales expuestos y, sobre todo, analizar con toda la profundidad que permite la documentación histórica las relaciones devocionales entre los fieles y los símbolos sagrados más queridos, en aquellos lugares donde más y mejor se veneran, y en particular en ciertos conventos madrileños. Para mejor interpretar estos contextos, nos centraremos en los conventos de la Santísima Trinidad Calzada y de los Agustinos de san Felipe el Real, dos centros espirituales que tuvieron cierta importancia con el culto madrileño a la Virgen de Peña Sacra.

Estos conventos, uno ubicado en una esquina de la Puerta del Sol (san Felipe el Real) y el otro muy cerca, al principio de la calle Atocha (Trinidad Calzada), acogieron en su seno las inquietudes devocionales de muchos madrileños, que tuvieron múltiples formas de expresarse y sobre todo de organizarse, siendo la más común la de la cofradía ${ }^{5}$. Los documentos históricos que se han podido consultar ${ }^{6}$ permiten forzar una tipología de cofradías que da cuenta de las organizaciones devocionales que ocuparon las redes de esta geografía religiosa y en la que destaco los siguientes puntos:

1. Un primer tipo de cofradía tiene que ver con la voluntad institucional del mismo convento de promocionar cultos a imágenes vinculadas directamente con la Orden. Su interés radica en una clara revitalización de las necesidades devocionales de los fieles mediante la creación de una organización controlada desde el convento. Este centro espiritual llega a concentrar en su seno numerosas y renovadas imágenes sagradas, con la condición de que sus cofradías les rindan siempre culto en el mismo convento, sin posibilidades de fugas ni de traslados. Este es el caso, por ejemplo, de Nuestra Señora de la Expectación, titular de su

tales de la capital que también pudieron convertirse en puntos de atracción devocional por las imágenes religiosas allí presentes. Ver al respecto en Antonio CEA, "Robada, prostituidad, restituida y siempre Virgen. El caso de Nuestra Señora de Madrid (Tradición oral y tradición escrita)", RDTP, LI, 1 (1996), pp. 57-127.

5 Las imágenes religiosas veneradas en los conventos no solamente quedaban vinculadas a los fieles por la organización de cofradías, sino también por la mediación del vínculo familiar. En efecto, hubo ciertos casos de venta, por parte de dichos conventos, de altares para fundaciones de misas, estipuladas en testamentos en forma de capellanías, que regeneran a su medida los espacios interiores de los templos. A pesar de su interés, las capellanías quedan fuera de este trabajo.

6 He consultado todos los legajos disponibles de dichos conventos que actualmente se encuentran en el Archivo Histórico Nacional, todos ellos sin catalogar, así como sus respectivos libros de acuerdos. 
altar en el convento de los Trinitarios Calzados, cuya cofradía, Dulce Nombre de María, fue fomentada y creada en 1612 por el trinitario Simón de Rojas ${ }^{7}$. En este contexto hallamos igualmente a santa Rita de Casia, venerada desde los altares de los Agustinos de san Felipe el Real en 1693, cuya cofradía llegó a tener la posibilidad de rendirle culto, a mediados del siglo xviII, en uno de los mejores altares de dicho convento, ocupándole con sus funciones después de haberlo dejado vacante sus antiguos titulares, los hermanos de la cofradía de Nuestra Señora de Guadalupe. Las dinámicas internas de estas cofradías (misas por los hermanos difuntos, celebración de sus fiestas, entierros de hermanos, etc.) están vinculadas a unas imágenes cuyo culto estuvo controlado por la Orden titular del convento desde sus inicios. Destaca, ante todo, la perdurabilidad de su devoción en el mismo lugar de culto, contraponiéndose de esta forma a las continuadas movilidades devocionales de otras cofradías.

2. Aunque no muy numerosos, encontramos los casos de cofradías reabsorbidas bajo la condición de un mejor ofrecimiento de la materialidad del culto. El convento llega a tener un cierto tipo de atracción hacia grupos de devotos cuando se les ofrecen óptimas condiciones para mejorar la calidad del culto a una determinada imagen religiosa. A diferencia de los casos anteriores, grupos de devotos localmente agrupados en una vecindad de barrio poseen su propia imagen; algo así como los actuales grupos de rezo colectivo. Los fieles a la Virgen de la Soledad y del Rosario, todos ellos vecinos del portal llamado Cabestreros en la Plaza Mayor, cambiaron su parecer cuando se les ofreció dar un salto cualitativo a su peculiar forma de rendir culto a dicha imagen. El traslado al vecino convento de san Felipe el Real fue debido al "deseo de que María Santísima estubiesse con más culto, deboción y beneración”; y la transformación en cofradía, en 1754, con centro de culto en dicho convento fue el resultado de una absorción de cultos más o menos periféricos y poco organizados $^{8}$.

3. Abundan cofradías surgidas de colectivos ya formados, como son los gremios artesanales. La ciudad de Madrid tenía en esa época un gran contingente de artesanos, agrupados en gremios. Estas categorías socioprofesionales tuvieron gran importancia en la vida religiosa de la capital, cuando surgió el interés por agrupar en cofradía a todos los varones ocupados en un mismo oficio. El sentimiento de formar parte de un colec-

7 Archivo Histórico Nacional. Clero regular-secular. Legajo: 4228.

8 A.H.N. Clero regular-secular. Legajo: 3725. 
tivo particular era suficiente para crear una hermandad que posibilitaba la creación de nuevos vínculos entre hermanos, una atractiva dimensión devocional, considerada la continuación de sus lazos profesionales. La búsqueda de imágenes religiosas en consonancia con sus actividades profesionales pudo ser una de las primeras tareas de los artesanos en proceso de conversión a cofrades. Algunos lo tuvieron fácil, como los carpinteros madrileños que encontraron en san José su imagen religiosa titular, pero a otros, les fue más difícil hallar correlaciones entre actividad profesional y atributos externos o relativos a la hagiografía de las imágenes; así, en los casos de advocaciones universales como Visitación, Remedios, Santiago, san Antonio Abad o Purificación, patronos de cofradías de albarderos, zapateros, sombrereros, esparteros y reposteros, respectivamente. Tal vez lo más importante es que, ante un contexto plural y ciertamente cargado de símbolos sagrados, la atracción devocional de las imágenes religiosas convertidas en patronas titulares de hermandades gremiales quedaba atrapada por los condicionantes sociales de sus miembros, algo encerrada en torno a un grupo de iguales que veían en su patrono la corporeización de su identidad de grupo ?

Sin embargo, el rasgo más característico de este tipo de hermandad fue el de instituirse en "cofradía de socorro". La regla interna más importante era la del "mutuo apoyo", una extensión de sus lazos profesionales en el campo de la beneficiencia ante la muerte. Muchas de las obligaciones de los cofrades estaban relacionadas con las prestaciones que ofrecían a sus miembros enfermos o difuntos, extensibles a sus esposas e hijos menores. Como tal grupo corporado, estaban interesados por las condiciones materiales y espirituales que les ofrecía un convento y, sobre todo, por el hecho de tener un lugar propio de sepultura donde enterrar a sus hermanos y honrar su memoria entre todos. En este sentido, los cofrades miembros del gremio de albarderos negociaron con los priores del convento de la Trinidad Calzada, en 1703, la posibilidad de comprar un pilar de altar para poder instalar sus dos imágenes sagradas patronas, Nuestra Señora de la Visitación y santa Isabel, así como enterrar a sus miembros ${ }^{10}$. Un lugar adecuado para celebrar sus fiestas particulares, ante sus símbolos religiosos, y poder enterrar a sus miembros fueron las condiciones

9 Algo parecido ocurrió en la Florencia de los siglos xv y xvI, y en gran parte de Francia entre los siglos xiII y xv. Ver Ronald WeISMmAN, Ritual brotherbood in Renaissance Florence (New-London: Academic Press, 1982); Christopher BLACK, Italian confraternities in the sixteenth Century (Cambridge: Cambridge University Press, 1989); Catherine VINCENT, Les confréries médiévales dans le royaume de France, XIIt ${ }^{e} \mathrm{XV} V^{e}$ siècle (Paris: Albin Michel, 1994).

10 A.H.N. Clero regular-secular. Legajo: 4220. 


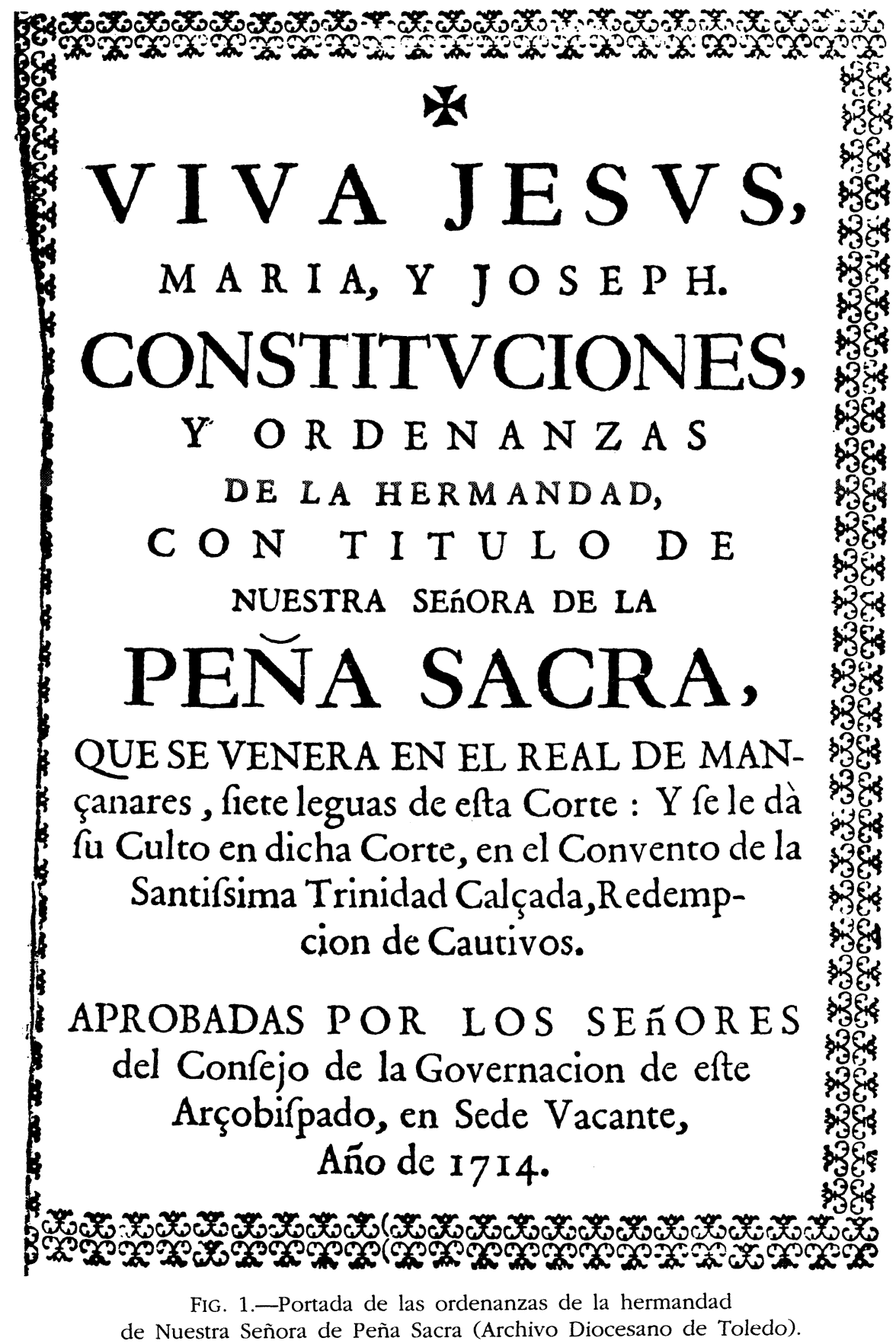


imprescindibles que confirmaron la radicación del símbolo sagrado en el templo del convento, lugares sagrados que legitiman el espacio elegido como lugar nodal de la geografía religiosa madrileña.

4. Otro grupo importante de cofradías son las que se agruparon en torno a una identidad regional común. La capital del reino atrajo, como centro administrativo y comercial, a muchos residentes procedentes de otras regiones del país, y de sus colonias, y como tales grupos de afines confirmaron sus expectativas asociativas mediante la creación de cofradías, cuyos símbolos sagrados fueron venerados por su valor altamente identitario. Los dos conventos mencionados fueron los lugares elegidos (entre otros muchos) por dichas cofradías para celebrar sus particulares cultos e impregnaron esta geografía religiosa madrileña, con su presencia, de un sólido componente social de larga tradición histórica, estando incluso en la actualidad presentes, aunque eso sí con otras connotaciones, con las casas regionales. Cada congregación de identidad regional elegía como imagen patrona un símbolo con clara resonancia de origen: los gallegos al apóstol Santiago (fundada en 1741), los indianos mexicanos a Nuestra Señora de Guadalupe (fundada el mismo año que la anterior), los montañeses a Nuestra Señora de la Bien Aparecida (fundada en 1777), los vizcaínos a san Ignacio de Loyola, los manchegos a santo Tomás de Villanueva (fundada en 1750, todas ellas en el convento de san Felipe el Real), los castellano-leoneses a santo Toribio Alfonso, arzobispo de Lima, (fundada en 1776 en el convento de los Trinitarios Calzados). Considerados como ailustres" congregantes por los priores de dichos conventos, con Reales atribuciones y diversas protecciones (el monarca era el hermano mayor de la de Nuestra Señora de Guadalupe), se diferenciaban de las cofradías de "Socorro" por tener mayores cuotas de prestigio, según la composición social de sus miembros, pero también por el enorme coste material que se empleaba y despilfarraba en la celebración de las fiestas en honor de sus santos patronos. No compartían las inquietudes de los cofrades de "socorro" respecto al apoyo mutuo ante las desgracias y muertes de congregantes. Su fin no estaba en ser "congregación de socorro, sino solicitar los mayores cultos de Dios y de María Santísima, su espezial amparo y protección" ${ }^{11}$. Las fiestas dedicadas a sus imágenes sagradas particulares no fueron más que la ocasión privilegiada de demostrar que el interés de dichas hermandades radicaba en perpetuar unos cultos particularizados en el lugar más apropiado. No les interesaba compartir funerales y entierros, puesto que la mayoría de sus congregantes ya poseía un

11 A.H.N. Clero regular-secular. Legajo: 3725. 
propio modelo fámiliar de enterramiento (mediante capellanía), en criptas o capillas en iglesias parroquiales o conventos, pero en sus lugares de origen.

Este esbozo de geografía religiosa madrileña, donde destacan los lugares en que se ubican las imágenes, cargadas de sacralidad con fuerte poder de atracción, sobredimensiona los puntos exactos de su culto. Pero no por ello hemos de entender que son lugares fijos e inamovibles para la celebración de los modos rituales. Esta geografía religiosa madrileña demuestra que el componente plural de sus agentes más activos determina los modos de acceso a dichos puntos nodales. Se puede entrever una consecuente movilidad de grupos de devotos, no en el sentido ritual de atracción del símbolo sagrado, sino más bien en una especie de inconsistencia de las formas de interrelación entre dichos agentes y las instituciones que legitiman los puntos nodales del territorio religioso. Tal movilidad puede captarse cuando las cofradías entran en contacto con los conventos para negociar los términos de sus relaciones. En cualquiera de sus solicitudes a los priores, los representantes cofrades estipulan todos los puntos que consideran importantes para la celebración de su particular culto. Estudiados por los priores, éstos les devuelven otras condiciones donde se negocian aquellos puntos conflictivos. Finalmente, se llega a un acuerdo entre unos y otros, y quedan estipulados todos los puntos que cada parte ha de cumplir. Con las cofradías de "Socorro", las negociaciones iban dirigidas más bien a la cesión, mediante compra, de un altar para celebrar el culto adecuado y enterrar a sus hermanos, cediendo el convento su altar mayor para la celebración de las fiestas anuales de la hermandad. De esta forma, el templo del convento quedaba ratificado en su propuesta de radicación de símbolos sagrados: las imágenes patronas de dichas cofradías quedaban ligadas para siempre a este legítimo lugar apropiado para el culto. La propuesta de la institución conventual parece ser la de fijar perpetuamente los símbolos sagrados de grupos corporados en su espacio propio (incluyendo a las hermandades fomentadas desde el convento), no solamente como punto de prestigio y rentabilidad económica, sino también para dejar establecidos los puntos nodales que han de tejer este territorio sagrado y ubicados en su lugar, con pretensiones de perpetuidad.

Sin embargo, en el caso de las congregaciones de identidades regionales, la tensión entre la pretensión territorializadora de los conventos y la movilidad descontextualizadora de dichas hermandades queda reflejada en los pocos acuerdos a que llegaban después de sus pertinentes negociaciones. La legitimidad del lugar ofrecido para el culto y su devoción es constantemente revisada por estos cofrades que dan libre curso a sus 
pretensiones. Todos sus acuerdos con los conventos plantean la posibilidad de irse a otro lugar para celebrar sus cultos sin que sean molestados en este traslado. Esta libertad de movimiento debe entenderse como el reconocimiento de la hermandad como dueña, mediante la compra, de sus imágenes religiosas, todo lo contrario de las cofradías rurales, cuyas imágenes patronas pertenecían a la iglesia parroquial. En 1741, la congregación de Santiago, libre de movimientos, como dueña de su imagen, en busca de un lugar adecuado para su culto, forzó en sus negociaciones con el convento de san Felipe el Real la ubicación de otra de sus imágenes, Nuestra Señora de las Barcas, al lado del Apóstol, desplazando para ello a una advocación de propiedad conventual, siempre con el peso de la amenaza de irse a una iglesia de su propiedad, que pensaban construir $^{12}$. La congregación de Nuestra Señora de Guadalupe, después de un periodo en el convento de san Felipe el Real, abandonó el lugar en 1757 para instalarse entre los Padres Agonizantes, maestros de enfermos de la Calle Fuencarral. Pero en 1770 decidieron volver, "sabiendo que en cada agrupación humana existen dos o tres personas díscolas", ocasionando una remodelación interna en el templo del convento, debido a la saturación de imágenes religiosas, y bajo la condición expresa de que ya no podrían disponer de la imagen de Nuestra Señora para llevarla a otro lugar ${ }^{13}$. Otro caso es el de la congregación de santo Toribio que consigue de los priores del convento trinitario las mismas condiciones de celebración de sus fiestas que las que tenía en el lugar donde las celebraba anteriormente: el convento de Portaceli de los clérigos menores de san Felipe Neri ${ }^{14}$. Esta libertad de movimiento, sin las ataduras del apoyo mutuo en la beneficiencia y entierros de hermanos, provocó continuas tensiones que alteraron los equilibrios internos de la geografía religiosa local, a pesar del control de las instituciones implicadas. En efecto, los acuerdos entre hermandad y convento eran suscritos con independencia del Consejo arzobispal puesto que sus representantes no llegaban a vigilar sus contenidos, aunque, eso sí, una vez creada la hermandad, debía solicitar la aprobación de sus estatutos al Consejo de gobierno del Arzobispo; para su visto bueno definitivo, el Consejo pedía a sus representantes, el visitador eclesiástico del Partido y el cura párroco donde estaba ubicado el convento, un informe positivo.

12 A.H.N. Clero regular-secular. Legajo: 3724.

13 A.H.N. Clero regular-secular. Legajo: 3728.

14 A.H.N. Clero regular-secular. Legajo: 4228. 
La modalidad de cofradía a que responde la fundada en honor a la Virgen de Peña Sacra es la última que nos queda por analizar. Tiene rasgos comunes con algunas de las comentadas anteriormente, pero, al mismo tiempo, se diferencia en lo esencial. En efecto, comparte con las cofradías de "socorro" la inquietud por la beneficiencia entre hermanos y el apoyo mutuo durante las celebraciones de honras. También se asemeja a las congregaciones regionales por un casi exagerado empeño en cumplir de la mejor forma con las festividades de su imagen patrona y ganar las indulgencias por custodiar tan preciado tesoro como era la Virgen venerada en Manzanares, así como el desinterés por enterrarse en alguno de los dos templos conventuales. Sin embargo, nunca fue considerada por los dos conventos que le brindaron su apoyo como una cofradía fundada en sus templos. La gran diferencia que la separó de las demás hermandades fue que nunca llegó a ser dueña de la imagen sagrada, nunca llegó a comprarla para venerarla posteriormente, sino todo lo contrario, la imagen ya existía creando su hermandad a posteriori. Por ello deben entenderse las dificultades iniciales de esta cofradía, sus momentos de formación, como la creación de una organización separada de su geografía religiosa natural, descontextualizada de sus puntos nodales.

En 1683 se crearon las primeras ordenanzas de una cofradía que rendía culto a la Virgen de Peña Sacra, venerada en Manzanares el Real, aprobadas por el Consejo de Gobierno del Arzobispo. Solo sabemos de ellas por referencia posterior, cuando, en 1723, se decidió renovarlas aa causa de ser mui diminutas y sin las expresiones que se requieren para los precisos cargos que hoy han recaido en ella" ${ }^{15}$. Sin embargo, ya, en 1714 , hubo un primer intento de renovación de las primitivas ordenanzas, también aprobadas por dicho Consejo, en el que se deja claro que se rinde culto a dicha Virgen en el convento de la Trinidad Calzada. Sus veintinueve artículos reflejan un claro interés por funcionar como cofradía de "Socorro": ayuda de hermanos enfermos, asistencia de médico, gastos de entierro etc., pero sin ninguna referencia a sepulturas en dicho convento. El culto a la Virgen de Peña Sacra quedaba agregado al interés general de su mutua ayuda, eligiéndola como "patrona para que con su Divino amparo y auxilio emplearse en repetidos actos de caridad, socorriendonos los unos a los otros ${ }^{16}$. Todo parece indicar que se trata

15 Archivo Diocesano de Toledo. Cofradía de la Virgen de Peña Sacra. Año 1723.

16 A.D.T. Cofradía de la Virgen de Peña Sacra. Año 1714. 
de un grupo de cofrades que busca una imagen sagrada para sus necesidades, imagen que ya se veneraba a más de ocho leguas (unos cuarenta kilómetros) de sus casas. Finalmente, en 1723, se volvieron a renovar sus estatutos con la consiguiente aprobación del Consejo de gobierno toledano. Esta vez podemos seguir los avatares de tales cambios y observar que esta renovada cofradía con la misma patrona tenía su centro de reuniones en el convento de san Felipe el Real. En primer lugar, un pequeño pero selecto grupo de cofrades estuvo presente en las dos fundaciones, de 1714 y 1723, coincidiendo en sus respectivas juntas directivas. En segundo lugar, las nuevas ordenanzas continuaron con el espíritu de apoyo mutuo, pero sin interesarse por enterramientos de cofrades en un determinado convento. En tercer lugar, al igual que en 1714 , se ha de celebrar una serie de misas en el convento citado, a cambio de la ocupación de alguna de sus salas para reuniones; algo así como una compensación por ocupar los locales. Con estos factores, quedaba dibujada la implicación de esta hermandad en la geografía religiosa madrileña del siglo XviII. Venerando una imagen sagrada en Manzanares el Real y rindiéndola culto en Madrid, indistintamente entre dos conventos muy cercanos entre sí, parece que estamos en presencia de un grupo de cofrades residentes en un mismo barrio donde se ubican los dos conventos, pero ligados a sus respectivas parroquias como lugares preferidos de enterramiento. Como veremos más adelante, dichos cofrades parecen haber sido antes devotos de la Virgen de Peña Sacra, más que un grupo socialmente definido, y particularmente implicados en demostrar su devoción a esta Virgen en el lugar natural de su veneración. Es como si importaran a la geografía religiosa madrileña los efectos milagrosos del culto a esta Virgen extraña pero con cierto reconocimiento devocional.

Hemos visto cómo una gran parte de las cofradías madrileñas era propietaria de sus imágenes patronas. Ubicadas en distintos puntos legítimos de la capital, conseguir hallar un lugar predominante, o al menos destacado, entre las congregaciones dependía en gran parte del poder de atracción de sus imágenes sagradas. Muchas de ellas eran importantes y no solamente eran veneradas por sus cofrades, sino que arrastraban a más fieles cuando se celebraban sus fiestas. Algunas llevaban en sí un importante sentimiento colectivo de sacralidad por ser delegadas de su matriz, como ya hemos visto con las congregaciones regionales, otras quedaban sujetas a la estricta normativa de los cofrades gremiales, y muchas más quedaban olvidadas con el paso del tiempo por ser poco relevantes. Ante tanta proliferación de advocaciones y la competencia surgida por los esfuerzos de sus respectivas hermandades, los devotos madrileños de la Virgen de Peña Sacra quisieron aprovechar su atracción devocional para 
situarse entre los mejores en el entramado religioso de la capital. En este sentido, su estrategia no parece que fuese única, ya que, al menos en el mismo periodo, se conoce el caso de la congregación madrileña en honor a la Virgen del Hoyo, venerada en el pueblo de Hoyo de Manzanares y celebrando su culto en Madrid ${ }^{17}$.

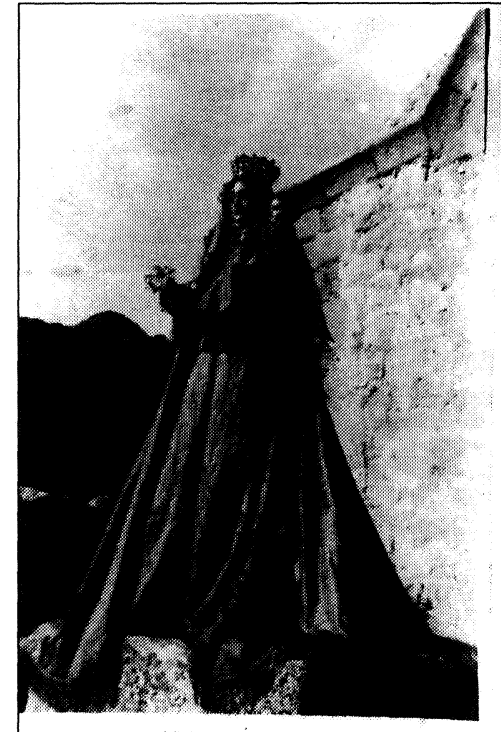

Fig. 2.-La Virgen de Peña Sacra ante su ermita (Fotografía cedida por Milagros González).

De los veinte artículos de las ordenanzas de 1723 , destacan dos en los que, a diferencia del caso de 1714 , se hace referencia al modo de celebrar el culto, adaptado al que se realizaba en esos tiempos en Manzanares. La distancia entre el lugar de veneración y el cumplimiento de su culto en forma de cofradía parece convertirse en uno de los problemas más graves de esta organización devocional. En efecto, existe una preocupación por parte de los cofrades madrileños en relación a los inconvenientes que supone venerar a una imagen sagrada a tanta distancia del lugar de residencia. Por ello, las ordenanzas precisan detalles relacionados con la estancia de los cofrades madrileños en Manzanares el Real. El más importante es la construcción de una "casa hospizio pegada a su hermita", donde un ermitaño ha de ocuparse de la manutención de los congregantes madrileños durante los tres días de fiesta y las funciones de Semana Santa en que se ganan indulgencias y jubileos. Cobijados de los fríos de la sierra, este refugio les permite disfrutar de su estancia devocional sin ninguna incomodidad. En segundo lugar, celebran la última misa el tercer día de la festividad, cuando la imagen vuelve a su ermita desde la iglesia parroquial, a primeras horas de la mañana, para poder regresar rápidamente a la capital, siendo rezada en lugar de cantada para acortar el tiempo lo máximo posible. Estas precisiones sobre el comportamiento y acomodo de los cofrades madrileños durante dichas fiestas son las que parecen desvelar los anteriores fracasos de 1683 y 1714: la adecuación de la veneración de la imagen sagrada en Manzanares con la práctica de su culto bajo la forma de una

17 A.D.T. Respuestas al interrogatorio del cardenal Lorenzana. Hoyo de Manzanares. Año de 1786. 
cofradía madrileña, salvando distancias e inconvenientes. Por ello, en 1723, la experiencia acumulada demostró la necesidad de eliminar estos factores negativos, "empeñarse" en rendir culto a esta imagen sagrada in situ, "a pesar de estar tan dilatada desta Corte la hermandad de Nuestra Señora a quien se dirigen estos cultos (..) no por este motibo se entienda ser en dicho conbento la fundazión desta congregación si no es en la referida hermita" ${ }^{18}$.

\section{UN RITUAL CONTROLADO}

La ermita de la Virgen de Peña Sacra era una de las seis atestiguadas en Manzanares desde el siglo $\mathrm{XV}^{19}$. Su mayordomo, elegido cada año por el concejo y la iglesia local, registraba los ingresos y gastos en un libro de cuentas, donde destacan hasta mediados del siglo xvir los mismos y monótonos registros: ingresos por rentas de cercas, limosnas de las fiestas y gastos relacionados con la recomposición de la ermita, así como los ornamentos litúrgicos necesarios. A partir de los años cincuenta de dicha centuria, el culto experimenta un cambio sustancial que se refleja en sus libros de cuentas. Por una parte, ya se hace mención de la existencia de ermitaño, con su pequeña vivienda colindante, y sobre todo, se aprecia la intensificación de los modos rituales en los que destacan mayores ingresos por limosnas, especificadas en llevar el pendón y estandarte de la Virgen, los cuatro brazos de las andas de su peana y su palio. Esta intensificación se ve reflejada en un aumento de devotos en las fiestas, no por los feligreses de Manzanares que siempre acudían a la cita, sino de otras muchas poblaciones cercanas. Tal vez influyera en ello el hecho de que Manzanares fuese cabeza de seis pueblos (El Boalo, Moralzarzal, Cerceda, Hoyo, Becerril y Mataelpino) hasta finales del siglo xviI, siendo la fiesta la reafirmación de sus lazos, pero lo cierto es que muchos devotos de otras localidades cercanas acudían en la Pascua de Pentecostés a la ermita de la Virgen desde Colmenar Viejo, Chozas (ahora Soto), Miraflores, Cabanillas, Guadalix, Fuencarral, Alcobendas... y Madrid ${ }^{20}$. Estos fueron, desde muy pronto, unos fieles muy activos para la expansión

18 A.D.T. Cofradías. Ordenanzas de Nuestra Señora de Peña Sacra. Artículo n. ${ }^{o} 15$.

19 Los demás titulares de ermitas eran: la Virgen del Vado, la Virgen del Campo, Santa Ana, San Silvestre y San Sebastián. Seis ermitas para una pequeña población que hasta el siglo XVI era cabecera del Real de Manzanares y cuyo señor fue el Duque del Infantado.

20 Archivo Diocesano de Madrid. Libro de cuentas, ermita Peña Sacra (1660-1686). 
del culto. Se especializaron en traer todos los años aun tablado de comedias" para engrandecer sus fiestas pero también se ocuparon de limpiar la lámpara de la Virgen en Madrid, en 1662. Una vez creada en 1683 la primera cofradía madrileña, los hermanos se obligaron mediante escritura a mantener una posición privilegiada en este culto, aasistiendo a su hermita con aceite para la lámpara que continuamente está ardiendo, cera, hornamentos y vestidos con todo lo demás necesario para el culto de Nuestra Señora, reparar su hermita y casa-hospizio" ${ }^{21}$.

Los devotos madrileños estuvieron implicados en el desarrollo y fomento de la atracción devocional de la Virgen de Peña Sacra, consiguiendo un "territorio de gracia" de ámbito comarcal, ubicado en la zona norte y central de la actual provincia de Madrid ${ }^{22}$. Pero además, este interés por fomentar y desarrollar su culto les llevó a fundar las distintas cofradías ya comentadas y sobre todo a elevar su nivel de implicación. En efecto, a partir de 1707, las cuentas controladas por los tradicionales mayordomos locales desaparecieron y fueron administradas por la junta directiva de la cofradía. Este mayor compromiso en asuntos devocionales locales fue percibido de forma bien distinta por las dos instituciones que más contribuyeron a mantener este culto: el concejo y la iglesia parroquial. Por parte del ayuntamiento, las iniciativas de los cofrades madrileños fueron siempre bien recibidas, puesto que el aumento de actividades durante las festividades en pro de una mayor difusión del culto a la Virgen atraía más comarcanos y aumentaba el orgullo local respecto a "Su" imagen sagrada. El concejo, incluso, colaboraba con los cofrades en estas actividades con el pago de su viaje desde la capital, así como con una ayuda importante para celebrar sus festividades ${ }^{23}$. Sin embargo, respecto a las relaciones con el representante de la iglesia parroquial, todo era distinto. Los cofrades madrileños vaciaron los espacios legítimos de ciertas personas muy vinculadas tradicionalmente con el culto y directamente controladas por el párroco. El primero fue el mayordomo, cuyas cuentas anuales ya no podían ser accesibles para el cura. El segundo fue el ermitaño, siempre nombrado y vigilado por el párroco. A partir de la década de los años veinte del siglo xviII, fue sustituido por otro ermitaño, curiosamente un fraile

21 A.D.T. Ordenanzas de la Virgen de Peña Sacra. Año de 1723.

22 El acertado término de "territorio de gracia" procede de W. Christian y es similar al concepto empleado aquí de ageografía religiosa. Por otra parte, en esa zona norte de la provincia de Madrid no abundaron los santuarios con una atracción devocional capaz de superar una área comarcal, siendo el más importante el de san Antonio de la Cabrera.

23 A.H.N. Sección de Hacienda. Catastro de Ensenada. Libro 357. 


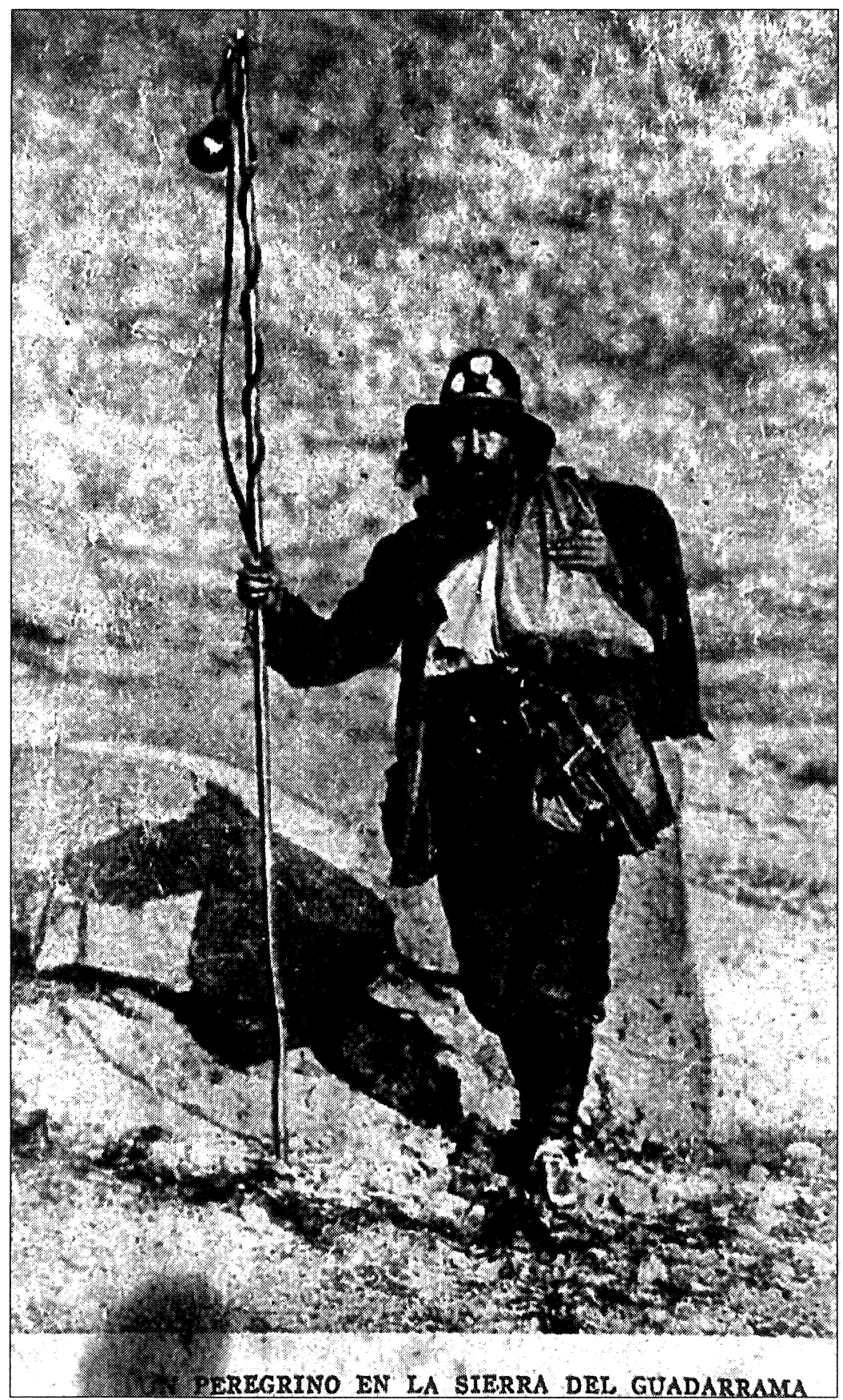

FIG. 3.-Ermitaño de Nuestra Señora de Peña Sacra (Fotografía cedida por Milagros González). 
agustino, que entregaba las cuentas directamente al tesorero de la cofradía, sin el visto bueno del párroco. Por último, el personaje que corría peligro de desplazamiento era el propio párroco. La cofradía tuvo interés en llevarse a Manzanares, desde la capital, varios sacerdotes que oficiaran durante las fiestas, argumentando que el cura párroco debía atender a los feligreses de su anejo y que quedaba abrumado por tanta tarea ante la afluencia de devotos, por lo que la mejor forma de solucionar este problema era traer otros sacerdotes para paliar el déficit ${ }^{24}$. El control de los modos rituales de esta festividad, mediante la sustitución de los principales agentes implicados en ella, fue una de las actuaciones más explícitas de la cofradía madrileña, pero no la única. Faltaba algo importante para completar el círculo: readaptar el tiempo ritual a sus necesidades. Lo intentaron unos años más tarde, en 1739. Solía llover por la Pascua de Pentecostés en la sierra y tales inclemencias del tiempo podían perjudicar y "entibiar" la devoción de los madrileños, solicitando su hermano mayor al Consejo de Gobierno del Arzobispo el cambio de fechas de celebración de las festividades, posponiéndolas hasta los días 29 y 30 de junio y 1 de julio, más acordes a sus intereses. Una vez aprobadas sus peticiones, ninguna institución local podía recuperar el periodo tradicional, ya que la congregación, según dicho hermano mayor, tenía derecho a determinar los tiempos festivos oportunos sin que eel cura y justicia de la Villa ni haya persona alguna con ningún motibo puedan remober la Santa Ymagen de su hermita y capilla [...] para hazer sus fiestas" ${ }^{25}$.

La desestructuración de los modos rituales tradicionales ejercida por esta congregación y su control sobre nuevas pautas, impuestas desde su posición legítima de única organización que podía rendir culto formalmente a la Virgen, no logró sin embargo contener los recelos de la institución eclesiástica, desde el párroco hasta el visitador del arzobispado. Al estar fundada en esta ermita, la cofradía dependía de su matriz, la iglesia parroquial y ésta a su vez, del control del visitador eclesiástico. Sus informes criticaban la autonomía de la cofradía que no se sujetaba a los controles diocesanos respecto a sus cuentas anuales. En verdad, no llegaron a conocer nunca el estado de sus ingresos y gastos, a pesar de saber por otras fuentes menos oficiales que "según me han contado se recogen mui crecidas limosnas y de rifas de diferentes alhajas que ofrecen los fieles y por otros medios además de los que annualmente se facilitan en los cepillos y cajas que dha congregación tiene puestos en varias partes de Madrid" ${ }^{26}$. No obstante, la hermandad continuó con su actividad desequili-

24 A.D.T. Carta del hermano mayor. Noviembre de 1723.

25 A.D.T. Carta del hermano mayor. Mayo de 1739.

26 A.D.T. Carta del visitador. Año 1732. 
bradora hasta alcanzar el más importante de todos los hechos analizados: forzar el cambio de patronazgo en Manzanares el Real. En efecto, la atracción devocional que se inició a mediados del siglo xvil forjó, poco a poco, una nueva geografía religiosa local, en la que la Virgen de Peña Sacra fue consiguiendo ubicarse en el lugar más alto de las preferencias devocionales de los locales. Sin embargo, este posicionamiento jerarquizado quedó en entredicho por la intromisión de los cofrades madrileños en el peculiar proceso. La intensificación de los modos rituales llevada a cabo por dichos congregantes desplazó a la población local y a sus representantes institucionales. Los tres días de la festividad fueron totalmente controlados y acaparados por los cofrades de Madrid. La tradicional presencia de feligreses y otros comarcanos quedó eclipsada por la masiva afluencia de madrileños en todos los actos religiosos, y, al mismo tiempo, los locales fueron expulsados de cualquier espacio de responsabilidad colectiva. Los feligreses, ausentes de su propia festividad, miembros pasivos de los acontecimentos festivos que cada año se repetían durante tres días, sin posibilidad para el protagonismo de ningún tipo, perdieron, poco a poco, la esperanza de recuperar el vínculo de patronazgo con su imagen sagrada. Miraron hacia otro lado y se fijaron en otra imagen religiosa ubicada en la iglesia parroquial para recuperar el tiempo perdido; a partir de esos años el culto al Cristo de la Nave empezó a desarrollarse hasta convertirse, en poco tiempo, en la imagen patrona de la localidad.

El 14 de mayo de 1769, durante las fiestas a la Virgen de Peña Sacra, una vez terminada la procesión, los cofrades madrileños cerraron las puertas de la iglesia parroquial sin percatarse de que el altarero de la hermandad había dejado encendidas unas velas que cayeron sobre el suelo de madera. El accidente provocó un gran incendio que "quemó todas las maderas de su techumbre, artesonado, puertas, altares, con su adorno, tribuna, escalera de la torre, campanas [...] de forma que no ha quedado más que las murallas, arcas, vóvedas" ${ }^{27}$. La imagen de la Virgen y otras muchas quedaron destruidas por el fuego ante el "gran desconsuelo de la población". Hasta 1773 no llegó a recuperarse el templo, cuyas obras fueron pagadas por la parroquia, así como la imagen de la Virgen que fue reconstruida mediante aportaciones locales. A pesar de la insistencia del párroco en involucrar a los cofrades madrileños, el silencio fue la respuesta. Y también su significativa ausencia. Dejaron de acudir por la Pascua de Resurrección como lo venían haciendo desde mucho tiempo atrás. Quince años después del incendio, el cura párroco redactó un informe donde se dice que "la imagen que existe en dicha ermita no es la origi-

27 A.D.T. Carta del notario. 15 de mayo de 1769. 
nal, unos dicen que la original se quemó [...]; otros son del sentir que la original es la que tienen los congregantes (que aunque pocos) existen en Madrid" ${ }^{28}$. La desconfianza y el recelo ya estaban presentes en las mentes locales, su imagen sagrada ya no era la de antes. Los tiempos de concordia expresados por los feligreses habían terminado para dar paso a la opinión general de hurto; la hermandad madrileña había sobrepasado un umbral difícilmente recuperable, el de la legitimidad de sus acciones y había perdido la confianza de los feligreses de Manzanares. Este fue el final de la aventura devocional de unos cofrades madrileños que quisieron eliminar las barreras entre veneración y culto, entre una devoción marcadamente rural y su organización religiosa, insertada en un complejo entramado urbano; en definitiva, salvar las diferencias entre dos patronazgos, el comunitario y el corporativo.

\section{ROBERTO FERNÁNDEZ SUÁREZ} UNED. Madrid

Se analizan las pretensiones de una cofradía madrileña del siglo xviII de rendir culto a una imagen mariana venerada en Manzanares el Real (Madrid). Insertada en una geografía religiosa variada y plural, esta cofradía mantuvo contactos con dos conventos madrileños, la Trinidad Calzada y san Felipe el Real, para legitimar su culto. Bajo una interesada campaña de control, consiguió, durante muchos años, eliminar cualquier elemento que pudiera hacerle sombra en todos los modos rituales de la festividad de la Virgen, hasta llegar a su manipulación completa.

The autor analyzes the aims of a 18th-century brotherhood in Madrid in promoting the cult to an image of Mary of Manzanares el Real, Madrid. This brotherhood, which incorporated and formed part of a specific and plural religious geography, operated in association with two convents of Madrid - Trinidad Calzada and San Felipe el Real- to legitimize the cult. By means of a self-serving campaign of control, the brotherhood destroyed, over decades, any element which could overshadow the cult in every aspect and type of ritual related to celebrations in the honor of Mary: a process that led to the complete manipulation of these celebrations.

28 A.D.T. Respuestas al interrogatorio del Cardenal Lorenzana. Año 1784. 